\title{
Entrepreneurial Behavior among University Students: Empirical Evidence from Pakistan
}

\section{Syed Ahmad Hashmi* and Shamila Nabi Khan ${ }^{* *}$}

\begin{abstract}
Interdependent relationships among various psychological factors are instrumental in shaping university students' general behavior toward entrepreneurship. Our study explored these relationships and their contingent and moderating effects through various factors, such as need for achievement, selfcontrol, and relational support, and how they influence entrepreneurial behavior, given the presence of variables like entrepreneurial intention, creativity, entrepreneurial self-efficacy, educational support, and personal attitudes. Primary data were collected through a questionnaire circulated among 300 respondents from two top-tier universities in Pakistan, followed by tests of reliability and validity both in SPSS and AMOS. The relationship testing was done through structural equation modeling using AMOS interpreted in terms of Alpha (at three significance levels) and Beta values for more regressed relationship testing. Results showed: a) significant behavioral tendencies of university students towards entrepreneurial behavior; $b$ ) the mediating effect of need for achievement was not significant among entrepreneurial intention and behavior relationship (however, this effect was significant when tested directly among these two variables); c) the moderating effect of self-control on the underlining variables was significant as a whole except for educational support; and d) relational support proved to moderate the relationship between personal attitudes and entrepreneurial behavior.
\end{abstract}

Keywords: Entrepreneurial intention, self-control, personal attitude, entrepreneurial self-efficacy, need for achievement.

JEL classification: C12, C91, 125, I28, L26,

\footnotetext{
* Research Associate, Information Technology University, Lahore, Pakistan.

${ }^{* *}$ Lecturer, Lahore School of Economics, Lahore, Pakistan.
} 


\section{Introduction}

Entrepreneurship has become an emerging phenomenon in Pakistan over recent years. This movement is driven by young university students and graduates with a keen interest in entrepreneurship. Studying for a good job seemingly is no longer the norm for the youth of Pakistan. This is likely the reason why preference is increasingly given to owning a business and implementing knowledge acquired through university education into that business. Entrepreneurial behavior is the product of this transition away from previous norms that has taken place. Adjusting to this transition, leading universities in Pakistan are opening entrepreneurial centers for coaching and funding of entrepreneurial initiatives for youth. Our study asks what the driving force is that is making university students more interested in entrepreneurship and shaping their behaviors accordingly.

Few studies have been conducted in Pakistan to explore this phenomenon, and there is much to be discovered about students' entrepreneurial behavior in Pakistan. Entrepreneurial intention is the primary element that conditions the behavior of university students to become an entrepreneur (van Gelderen, Kautonen, \& Fink, 2015), driven by a need for achievement within a student's mind. This need for achievement is natural and linked to the ambitions and goals an individual might have (Zeffane, 2013). Need for achievement is a mediating factor that is subject to further investigation as one of the initial driving forces of entrepreneurial behavior. Self-efficacy and creativity are other aspects that shape student behavior that this study investigates. These factors tend to vary among individuals and ultimately effect behavior positively or negatively with regard to entrepreneurship.

Underlying each of the other factors is self-control; exercised by the students and expressed in the form of a final decision, at which they arrived by rating and prioritizing entrepreneurial initiatives into their future plans of action. This study targets the effect of these aspects through a multidimensional variables study among university students. The success and failure rate of the entrepreneurial initiatives is linked to how well the entrepreneurial behavior is shaped during the university study tenure of a particular student (Valliere, 2015). As entrepreneurship generates a natural drive forward, attributes such as self-efficacy and selfcontrol are instrumental with regard to final behavior shaping. 
It is important to mention a few moderating factors investigated in this study. Self-control and relational support have a moderating effect on entrepreneurial behavior. These factors have a natural holistic impact which cannot be detached from either side. The aim of this study is to explore all the possible outcomes of such moderating effects and uncover the underlying principles, if any. Moreover, an aspect such as educational support is also considered vital for discussion in this study. The transition phenomenon mentioned previously is a definitive outcome of educational support. Entrepreneurial guidelines and concepts in the past have not been very accessible for students in university courses, but when it was made part of the curriculum, a need for such initiatives began to develop. Therefore the effect of related educational support on students should be considered when exploring. Behavior is shaped primarily by personality that has multiple attitudes embedded within it (Ghasemi, Rastegar, Jahromi, \& Marvdashti, 2011). Therefore, personal attitudes also should be investigated as a motivating driver to become an entrepreneur. However, this cannot be done in isolation as factors such as relational support can facilitate attitudes (Gedik, Miman, \& Kesici, 2015).

The way in which a person responds to a particular situation varies a great deal across individuals and that is perhaps what separates the generic from the exceptional. Personal attitudes towards entrepreneurial initiatives are more positive if there is the presence of relational support. This relational support can be an important factor in determining later entrepreneurial success (Turker \& Selçuk, 2009). To formulate a final verdict regarding entrepreneurial behavior building among university students in Pakistan (van Gelderen et al., 2015), it is necessary to explore the significance of the relationship between personal attitudes and relational support. Considering the current state of economic affairs in Pakistan there is space in the market for entrepreneurship to expand exponentially. This is the market opportunity analysis surrounding the student entrepreneurial platform in Pakistan and entrepreneurial behavior clearly relates to this analysis. An idea sells; this is the primary notion that makes entrepreneurship attractive to university students, as the flow of information around the globe today is vast and it is quickly facilitated. This makes young minds more enthusiastic and passionate about entrepreneurship (Gaddam, 2007).

The central idea of this study is to match the factors which make university students interested in becoming entrepreneurs with the likelihood that they can be inventors of ideas that have global appeal. The method by which entrepreneurial behavior is shaped has been 
investigated, identifying factors with positive links to this phenomenon. There are exceptions, but this study focuses on the main-stream entrepreneurial activity demonstrated by emerging university student entrepreneurs (Rauch \& Hulsink, 2015).

Entrepreneurial behavior is a specific behavior that should be explored through the impact of underlying factors, with mediating and moderating aspects as well. The impact of these underlying factors positive or negative - is under investigation. The causes of entrepreneurial behavior need to be assessed while considering the impact of the underlying factors. This study investigates entrepreneurial behavior as an outcome of intention, self-efficacy, educational support, personal attitudes, and creativity.

\subsection{Theoretical Underpinnings}

This study aims to explore the rationale behind the relationship between a selection of underlying variables and entrepreneurial behavior growing among university students. These underlying variables include entrepreneurial intention, creativity, entrepreneurial self-efficacy, educational support, and positive attitudes. The significance of these relationships is evident from the mediating and moderating relationships that exist in this proposed framework. The relationship between entrepreneurial intention and entrepreneurial behavior is subject to mediation by the need for achievement. Similarly, self-control moderates the relationship between entrepreneurial behavior creativity, and selfefficacy. In this study relational support moderates the relationship between positive attitudes and entrepreneurial behavior.

Entrepreneurial intention has a significant positive relationship with entrepreneurial behavior building that is mediated by the need for achievement. This relationship has been investigated in previous studies indirectly via explanation of the key aspects that drive entrepreneurial intention among university students. The student intent and urge to be an entrepreneur is explained by the fact that they can implement their ideas and thoughts in the work they can fully control and monitor (Turker \& Selçuk, 2009), which eventually is a product of their high confidence level resulting in entrepreneurial behavior building that is driven by need of achievement originally (Okhomina, 2010). The primary governing characteristics of self-control are strength of intention and taking action (van Gelderen et al., 2015). Creativity also effects entrepreneurial behavior building as the extent to which a student is imaginative and artistic drives 
his/her behavior to be an entrepreneur (provided the self-control moderation aspect) (Schmidt, Soper, \& Bernaciak, 2012). The ability to create ideas and put those into action determines the entrepreneurial career choice among university students (Ishiguro, 2015).

Entrepreneurial self-efficacy determines entrepreneurial behavior building provided the moderating effect of self-control is present. This is mainly due to the fact that students discover, evaluate, and exploit entrepreneurial opportunities based on the confidence they have in their capabilities to be an entrepreneur (Saeed, Muffatto, \& Yousafzai, 2014). It has been shown that entrepreneurial action is dependent upon entrepreneurial self-efficacy (Gielnik, et al., 2015). Educational support is another underlying variable that results in building entrepreneurial behavior among university students in the presence of the moderating effect of self-control. Educational support has a significant impact on perceived entrepreneurial behavior control (Yurtkoru, Kuşcu, \& Doğanay, 2014), due primarily to it shaping the thinking and psychological dimensions of the human mind. For the variables creativity, entrepreneurial self-efficacy, and educational support, self-control is the moderating variable that inherently governs the impact of these underlying variables on entrepreneurial behavior of university students. Personal attitudes are a fundamental aspect of entrepreneurial behaviors and intentions (Gedik et al., 2015). This may be the primary reason for a proposed positive relationship between personal attitudes and entrepreneurial behavior in this study, in the presence of the moderating effect of relational support. Relational support is instrumental to this relationship because individuals who are motivated to become an entrepreneur feel supported if someone in their group of friends/acquaintances supplements their proposed efforts. Entrepreneurial initiatives are positively related to relational supports that primarily comprise sentimental and monetary cushions from family and friends (Turker \& Selçuk, 2009). The theoretical framework is shown in Figure 1. 
Figure 1: Theoretical Framework

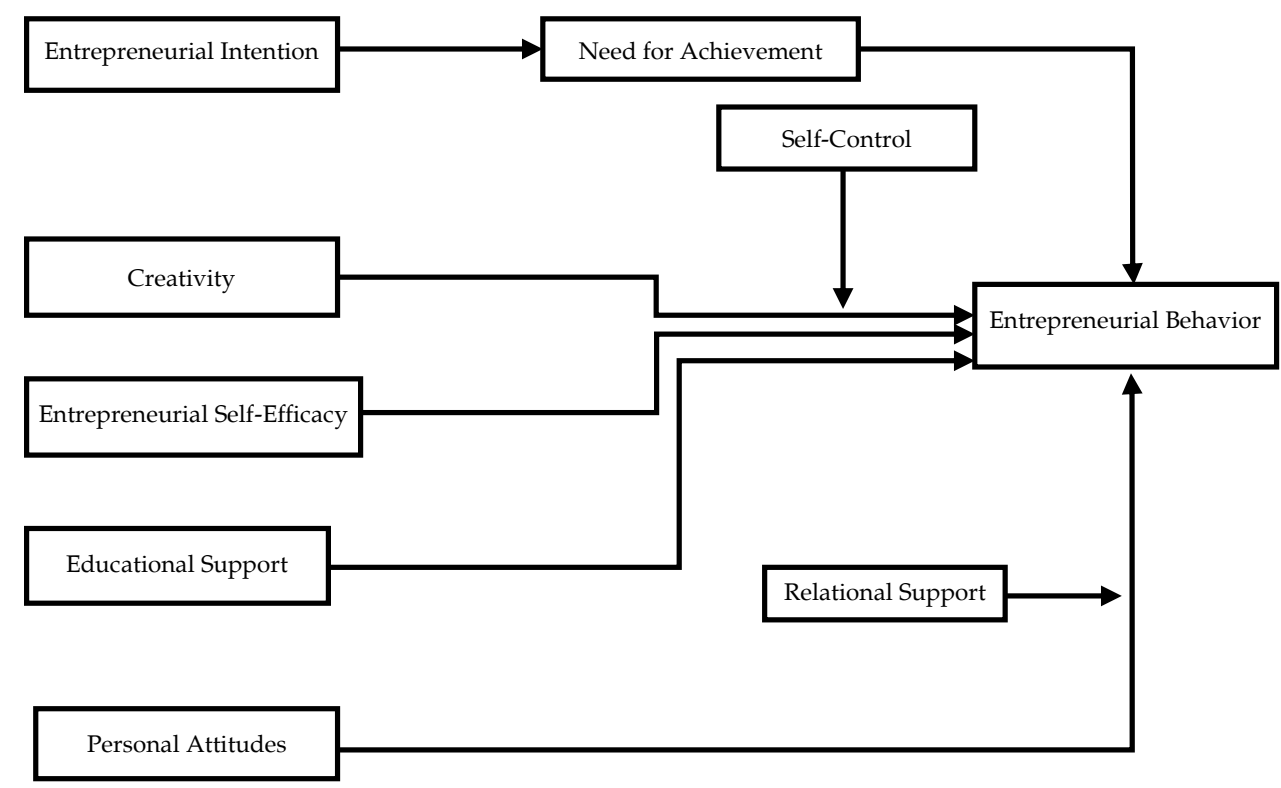

Entrepreneurial behavior among university students has numerous causes associated with it that are explained by the underlying variables proposed in this study. Entrepreneurial behavior among university students is an outcome of various psychological and environmental aspects that shape a student's mind continuously during the course of their education at the university (Rauch \& Hulsink, 2015). Entrepreneurial orientation that an individual develops over time also explains the entrepreneurial behavior that is displayed through the future course of actions in which he/she is involved (Moruku, 2013).

The interaction among different influencing factors and variables on entrepreneurial behavior (Gaddam, 2007) create a chain of interconnecting concepts that explain this entrepreneurial behavior. These factors can be the level of creativity, self-control, and basic intent to opt for self-employment. Entrepreneurial behavior is a holistic and dynamic process (Nitu \& Feder, 2012) driven by opportunities and self-capability analysis performed by an individual. The summation of the aspects of entrepreneurial behavior building converge at the theory of planned behavior (Ajzen, 1991) that states that behavior is composed of a systematic set of thinking processes that an individual undergoes over time (van Gelderen et al., 2015). 
Further, Krueger, Reilly, and Carsrud (2000) focused on intention shaping over time as it is linked to the continuous thinking processes taking place within an individual. Most importantly, the opportunities and threats against a potential business idea, as well as surrounding factors like availability of funds and economic conditions of a country, dictate how a young entrepreneur pursues his/her business plan. Souitaris, Zerbinati, and Al-Laham (2007) further expanded the landscape of student entrepreneurship by tapping the science and technology student base, investigating how their subsequent intentions can be shaped with regard to new business ideas and plans.

Entrepreneurship education as a means of awareness has been highlighted in this study and has been linked to inspiration as an emotional element behind the planned behavior. The personal attitude complement has also been touched upon as having a contingent effect on behavior. Intention-causing action was endorsed by this study. Ahmed et al. (2010) focused on entrepreneurial career building having a dependency on various personality traits and demographic aspects that contribute to the attitude of university students in Pakistan towards self-employment. Innovativeness in the thinking processes was weighed appropriately in the analytical conclusions: that is the intention that motivates a student to pursue entrepreneurship, and only then if the thinking processes are broad, and inspired by the right frame of reference can it emerge as a substantial venture.

As has been stated previously, there are numerous underlying factors that lead to an increase in entrepreneurial behavior among university students. The relevance of each of these factors is under investigation in this study.

\subsection{Discussion of Constructs}

\subsubsection{Entrepreneurial Intention}

Entrepreneurial intention is highlighted in various studies as a primary factor directing entrepreneurial actions (Moruku, 2013). The behavioral aspect of entrepreneurship is used as an embedded element within entrepreneurial action. According to Linan (2008), entrepreneurial intention emerges as a combination of cognitive processes that drive the behavior of an individual towards entrepreneurial initiatives. The same study validated the positive relationship between behavioral control and entrepreneurial intentions. The most significant predictor of human 
behavior is the intention of an individual (Krueger, 2008). This aspect has been explained in the context of entrepreneurial behavior as building dependently with the underlying intentions (Yurtkoru, et al., 2014). Overall studies have uniform findings regarding the positive relationship between these two variables (Turker \& Selçuk, 2009; Valliere, 2015; Ozgul \& Kunday, 2015).

\subsubsection{Entrepreneurial self-efficacy}

According to Gielnik, et al. (2015) self-efficacy is an action regulatory factory that governs the extent of entrepreneurial actions and behaviors. The self-beliefs of possessing the ability to undertake and successfully perform entrepreneurial functions have been validated by various studies (Townsend, Busenitz, \& Arthurs, 2010). The point of explanation here is the general tendency of individuals to believe in their instincts that they can opt for self-employment initiatives and succeed in practical life. In various studies a direct positive impact of self-efficacy on entrepreneurial behavior has also been identified (McGee, Peterson, Mueller, \& Sequeira, 2009). This signifies the fact that entrepreneurship as a behavior is not just confined to some behavioral theories, but in fact comprises prompt thinking processes and actions like self-efficacy.

\subsubsection{Creativity}

Various studies have identified creativity as foundational for effective entrepreneurial actions (behaviors inbuilt). This aspect attempts to explain the out-of-the-box abilities and solutions that an individual may have that stand out as a qualification to be an entrepreneur. According to Ishiguro (2015), MBA students rank low as compared to entrepreneurs in two factors namely autonomy and creativity. Student entrepreneurship needs to have creativity as well other aspects to be competitive in the selfemployment industry. Hamidi, Wennberg and Berglund (2008) found that high ratings on creativity drove positive entrepreneurial intentions.

Fillis and Rentschler (2010) found that entrepreneurial experience alone is not the dominant aspect in entrepreneurship, as it must be paired with creativity to lead to successful entrepreneurship. Thus, creativity is an important underlying factor that should be investigated in student entrepreneurship. 


\subsubsection{Educational Support}

Previous research studies have focused on educational support as a prerequisite for entrepreneurial career selection and behavioral makeup (Turker \& Selçuk, 2009). Various studies are of the opinion that degree programs in universities and colleges must focus on entrepreneurial initiatives study as compulsory (Couto, Mariano \& Mayer, 2014). This would have the effect of shaping the students thought processes. According to Yurtkoru et al. (2014) educational support is positively related to behavioral control. This illustrates the necessity for the course content of universities and colleges to have a considerable number of entrepreneurship guidelines so as to refine the self-employment abilities of individuals. All studies therefore have converged upon the same notion that entrepreneurship needs to be taught so that it becomes a general phenomenon (Turker \& Selçuk, 2009).

\subsubsection{Personal Attitudes}

Personal attitudes have been identified in past studies as a part of the theory of planned behavior (Ajzen, 1991). The literature suggests that personal attitudes directly impact entrepreneurial behavior patterns (Turker \& Selçuk, 2009). Attitude has been explained by various studies as the basic way of responding to an underlying task. Linan (2008) explains that the personal attitudes of an individual are driven by values and evaluations of the entrepreneurial activity of the larger society to which he/she belongs.

This is merely a reflection of social acceptability of entrepreneurial initiatives which ultimately shapes the attitudes of individuals. Studies have converged upon the point that both males and females exhibit a positive and energetic attitude towards becoming involved in entrepreneurial activities (Gedik et al., 2015).

\subsubsection{Need for Achievement}

The role of need for achievement as a mediator in the relationship between entrepreneurial intention and entrepreneurial behavior has not been investigated directly in previous research, but some indirect relationship derivations have been seen in the literature with regard to this mediating role. According to Zeffane (2013), young adults have the most intense need for achievement when faced with the challenge of being a successful entrepreneur. The mediating role is validated indirectly as the 
intention to express entrepreneurial behavior naturally comes prior to exhibiting the intended behavior (Zain, Akram \& Ghani,2010). Many researchers have concluded that need for achievement is significantly related to entrepreneurial activity (Segal, Borgia, \& Schoenfeld, 2007). Based on previous studies the mediating role of need for achievement is likely to be important as entrepreneurial potential is largely driven by such factors.

\subsubsection{Self-control}

Past studies have no direct evidence regarding self-control's moderating effect on the relationships of entrepreneurial self-efficacy, creativity, and educational support with entrepreneurial behavior. However, traces of such moderating effects are present in some studies. Van Gelderen et al. (2015) explains self-control as the ability to exercise willpower and the subsequent moderation exerted upon intention and action validates the proposed relationships.

Schlaegel's and Koenig's (2014) meta-analysis of the intention and action gap in entrepreneurship also explains the likely fit of self-control as a moderator in the proposed relationship. Several studies conclude that self-control is instrumental to behavior of all sorts, including entrepreneurship (Gross, Richards, \& John, 2006).

\subsubsection{Relational Support}

Past research has observed no direct evidence of the moderating effect of relational support in the relationship of personal attitudes with entrepreneurial behavior. However, relational support is documented in the literature with regard to its impact on entrepreneurial behavior (Yurtkoru et al., 2014). In its findings, this study reported that relational support significantly impacts both entrepreneurial intention and behavioral control. Other studies have considered relational support as a subjective norm that also impacts personal attitudes (Turker \& Selçuk, 2009). Past studies have merged the relational support aspect with the social networks of an individual which supplement his/her entrepreneurial behavior (Kraaijenbrink, Groen, \& Bos, 2010). Studies have converged upon the point that the career choice to become an entrepreneur is driven largely by the psychological comfort zone of having some relational or social network support (Dwyer \& Cummings, 2001). 


\subsection{Empirical Setting}

The research conducted in Pakistan on the entrepreneurial behavior building elements of university students are limited, as they generally lack a point of convergence as to what governs the ultimate drive of entrepreneurship among university students in Pakistan. Tanveer et al. (2011), made an attempt to analyze the factors that act as a barrier for business students to become entrepreneurs. The study tapped the subjective norms as part of a theory of planned behavior and identified weak financial resources and weak economic conditions of the country as discouraging influences on the entrepreneurial intentions of business students. Aslam, Awan, and Khan (2012) laid emphasis on family background as being the fundamental aspect controlling entrepreneurial behavior.

According to this study, personal attitudes are shaped by a family background that corresponds to any sort of business activity. However, this research did not explore the multidimensional underlying factors of self-efficacy or creativity. Tanveer, Shafique, Akbar, and Rizvi (2013) conducted research on the intentions of business graduates and undergraduates to become entrepreneurs. This study focused on factors like role of gender, entrepreneurial education, and the role of the university in shaping the intentions of students. The study pointed out that students have a clear perception of what having a job entails, rather than being selfemployed. This can be attributed to the factors under analysis, as the aspect of intention judgment was not considered; for example, the role of the university was not considered instrumental to entrepreneurial intentionbuilding in any way. Similarly, Sial and Chudhry (2011) conducted a comparative study on the low inclination toward entrepreneurship of business students in Islamabad. The primary limitation of this study was its sample size of only 20 students from various universities in Islamabad.

This research concluded that entrepreneurial orientation is very low among the business students in the city of Islamabad. However, this study did touch upon factors like entrepreneurial education and risk levels underlying the behavioral control. Saeed et al. (2014) conducted a comprehensive study on entrepreneurial education among Pakistani university students that included measurement items such as need for achievement and risk-taking propensity to explain how entrepreneurial education can supplement the intention to become an entrepreneur. However, factors such as self-control, creativity, and behavioral patternshaping were not part of this study. The literature is incomplete with 
regard to the study of entrepreneurship behavior in Pakistan. Perhaps there is a gap to be filled through further research on this behavior. See Table 1 in the Appendix for Findings of Research on Student Entrepreneurship in Pakistan.

\section{Research Methods}

\subsection{Measures}

The proposed framework attempts to explain the influence of some behavioral and psychological aspects that are responsible for introducing entrepreneurial behavior among university students in Pakistan. This behavior does not occur naturally; instead the factors proposed in the study are expected to influence such behavior. Entrepreneurial intention is mediated by the need for achievement within an individual that ultimately acts a motivator for him/her to behave in an entrepreneurial manner. This generates the motivation for the individual to get involved in selfemployment activity, rather than the traditional job search. Self-control corresponds to the stability and proper utilization of senses to act rationally. This rationality factor is also a substantial moderator of some other relationships in this proposed framework. Creativity is considered the clarity of an individual's thoughts to think beyond his/her capabilities and horizons; it is also moderated by self-control to ultimately influence student entrepreneurial behavior. Creativity is the single element that enables entrepreneurial activity to achieve exceptional results in terms of growth and expansion. This aspect relates to innovative solutions to existing gaps or problems in the business landscape. Entrepreneurial selfefficacy explains the internal systems' harmony within an individual that gives him/her the courage to believe in his/her instincts to opt for selfemployment.

Entrepreneurial self-efficacy is also moderated by self-control which fine tunes an individual's efficacy to start his/her own business venture in a self-sustained manner. This involves prudent use of available resources and selecting reasonable investments to nourish the business operations. Educational support has also been proposed to impact entrepreneurial behavior, moderated by self-control. This explains the phenomena that educational courses on entrepreneurship are instrumental to an individual's thought processes. During the shaping of these thought processes, stability of decision-finalizing and correct decision-making is highly dependent on self-control exercised by an individual. Moreover, personal attitudes have also been proposed in this framework as a factor impacting entrepreneurial behavior, but the moderating impact in this 
relationship requires further explanation to develop proper understanding. Relational support being a morale support, as well as a source of financial assistance through peers and family, influences personal attitudes and tendencies to become self-employed. Through the entire framework we intend to analyze entrepreneurial behavior across numerous aspects so as to create a clarified view of what causes such behavior.

\subsection{Sample}

The sample size determination was based on convenience sampling of 350 university students from two top tier business schools of Lahore. This was to ensure that there were two sets of contrasting opinions with regard to the questionnaire survey used to investigate the impact of underlying factors on entrepreneurial behavior. The sampling was not random because it was naturally based on selection on the part of the surveyor while moving through the various premises inside both educational institutions. There is no anchor study to follow as the questionnaire is wholly targeted at university students and not the general public.

The socio-demographic aspect in terms of student entrepreneurship needs consideration as one business school draws from areas of higher socio-economic status for its student body, whereas other draws students from all over Punjab and varied socio-economic levels. The combination of the questionnaire results from both institutions may produce diversified data to be analyzed. This is a primary reason why no anchor study has been used for sample size determination.

\subsection{Questionnaire}

For this research, data collection was conducted via a questionnaire comprising a combination of instruments. Questionnaires related to each of the independent, mediating, moderating, and dependent variables have been merged together to make a single comprehensive questionnaire that the respondents were provided. A total of 38 items is under investigation with varying scales of measurement used.

Self-control was measured on a 5-point Likert-style scale (Tangney, Baumeister \& Boone, 2004). Entrepreneurial intention, educational support, relational support, and personal attitude was measured on a 5point Likert-type scale ranging from "strongly agree" to "strongly disagree" (Entrepreneurial Intention Questionnaire (EIQ) scale developed by Liñán and Chen, in 2009) (Liñán \& Chen, 2009). 
The entrepreneurial behavior measurement was based on questions from three different sources: the PSED study (Gartner \& Carter, 2003), the Global Entrepreneurship Monitor (Reynolds, Hay \& Camp, 1999), and the Chamber of Commerce (Rauch \& Hulsink, 2015). This resulted in the creation of a list of 19 behaviors linked to entrepreneurship. To create a single scale for entrepreneurial behavior, binary yes-no questions were connected to these items (as suggested by Alsos \& Kolvereid, 1998,; Gartner, Carter, \& Reynolds, 2010; Souitaris et al., 2007). Creativity is measured on a 5-point scale: (a) "agree" to (d) "disagree", as has been proposed by a past study as a means of common factor analysis (Ishiguro, 2015). Need for achievement is measured on a 5-point Likert scale ranging from 1"completely disagree" to 5 "completely agree" formulated by Carter et al., 2003. Entrepreneurial self-efficacy was measured using a 5-point rating scale $(1=$ "very little confidence" to $5=$ "complete confidence") (Carr \& Sequeira, 2007). A description of each questionnaire used in this study is presented below. See Table 2 in the Appendix for Instrument Description.

\subsection{Data Collection Procedure}

The data collection procedure involved primary data collection through questionnaires given to students on the premises of a university. The questionnaire is interesting as it features elements common in conversation among university students relating to career selection. A higher response rate can be expected in this regard. However, an important aspect of procedure is the proper explanation of research protocol and resolution of any questions that the respondent might have while completing the questionnaire. This questionnaire is self-administered. As the MBI manual (Maslach, Jackson \& Leiter, 1996) has advised, respondents fully completed the questionnaire and avoided discussing the questionnaire items with others; this helped to reduce response bias. Questionnaires containing any unfilled sections or with double-option selections were identified and those questionnaires were eliminated from the study.

\subsection{Data Analysis}

This section aims to provide empirical evidence for the relationships proposed by the research hypothesis of the study. Reliability and validity of testing instruments formed part of analysis with the prime intent to substantiate the significance of the study. Entrepreneurial behavior-building was proposed to be based on several factors, among which statistical tools like SPSS and AMOS restricted some variables from 
further study; the framework was amended to reflect this. Analysis of entrepreneurial behavior-building was regression tested in AMOS with a $\mathrm{p}$-value at three significance levels $(1 \%, 5 \% \& 10 \%)$. Analysis of beta values was the basis of the structural analysis to follow.

Essential elements of a good test are the validity and reliability of the items within a questionnaire. The appropriateness and meaningfulness of the test results is referred to as validity. Both construct reliability (SPSS) and composite reliability (AMOS) formed part of the analysis. Confirmatory factor analysis (CFA) is the primary basis of validity and reliability testing. Divergent validity and factor loading of individual questions is also applied. The degree to which individual items in a questionnaire comprising the test is correlated with each other or with the total of the test is referred to as the internal reliability and Cronbach's coefficient alpha measure is used in this regard.

Comparisons of reliability estimates in terms of construct reliability provided by SPSS and composite reliability provided by AMOS analysis formed part of the explanations. Convergent validity and divergent validity testing was used to support the inclusion of items in the questionnaires, as proposed in previous studies (Zapkau, Schwens, Steinmetz \& Kabst, 2015). The relationship testing was based on similar relationship comparisons as utilized by various international studies. It has also been ensured that response diversity with regard to respondents' background is multivariate so as to have a close estimate of student entrepreneurial landscape within and across Pakistan (Usaci 2015). The primary analysis used was a CFA along structural model fit.

All variables were analyzed using correlations. Means, standard deviations, and percentiles analysis of each variable were calculated. There were five independent variables, two moderating variables, one mediating variables, and one dependent variable. Each component's analysis was done to evaluate the general responses for each variable prior to conducting the main analysis and testing of the relationships in AMOS. A general correlation analysis among all the variables allowed us to develop a basic foundation for relationship testing and provided a notion as to what sort of relationship this study is proposing compared to what is already present in the literature. See Table 3 in the Appendix for Descriptive Statistics.

These descriptive statistics highlight the relative importance of each variable in this study with regard to overall student responses. 
Similarities between each of the variable means indicates that a majority of respondents showed inclination towards accepting the variables that ultimately resulted in entrepreneurial behavior-building or were a source of entrepreneurial behavior. The deviations about the mean also were consistent with the mean interpretation stating that there is unanimity in terms, factors, and causations. See Table 4 in Appendix for Correlation.

Entrepreneurial intention is significantly positively correlated with relational support, need for achievement, self-efficacy, creativity, personal attitudes, educational support, and entrepreneurial behavior. However, it is negatively correlated with self-control. Self-control has a significant relationship with self-efficacy, creativity, and educational support. This suggests that among these important variables, the element of self-control is detrimental. These descriptive statistics explain that entrepreneurial behavior has a strong relationship with all the underlying variables except for need for achievement. This was further tested in AMOS.

Test of validity was done primarily in AMOS for this study. The CFA Table was the basis for testing the discriminant validity and convergent validity of all the underlying variables, which was a depiction of overall construct validity. The validity measures tested how well the questionnaire used in this study measured its claims as a relevant test tool. Factor loading comparisons formed part of analysis in this section to test the validity of individual questionnaire items. See Appendix for Table 5 on CFA.

The convergent validity figures for all variables ranged from 0.4 to 0.5 , with the exception of the variable creativity that had a convergent validity of less than 0.4 (Crook, Shook, Morris, \& Madden, 2010; Short, Ketchen, Combs, \& Ireland, 2010). The theoretical relationship between measures of constructs was tested by convergent validity (Mullen, Budeva, $\&$ Doney, 2009). However, in the case of creativity the reliability was lower than that, and the reliability analysis that follows was used to further analyze this variable. Divergent validity was also satisfactory in accordance with the standard ranges for all variables (Zapkau et al., 2015). See Table 6 in Appendix for Factor L.

Factor loading in CFA (AMOS) for each item should not be less than 0.4 (Ford, MacCallum, \& Tait, 1986). The factor loadings of all the items supported by the literature are available. Those items without support in the literature are in line with the standard loading estimates. Factor loadings here intend to validate that the items included in the 
questionnaire reflect previous literature findings. The included items have already been tested in various other research studies. See Tables 7 and 8 in Appendix for Reliability Tests.

In this study, both composite and construct reliability testing form part of the tests for reliability. With regard to the literature, all the anchor articles support the composite reliability figures generated by the AMOS covariance analysis. Composite reliability has more regressed values for Cronbach's Alpha than construct reliability in SPSS. A prior check for reliability was conducted in SPSS for construct reliability to better equip the data analysis before AMOS testing. The research findings for reliability are in accordance with the recommendations given in the literature: .60 to .70 alpha value (Mullen et al., 2009). High consistency is indicated by Cronbach's alpha values ranging from .73 to .97 (Nunnally, 1978).

\subsection{Hypotheses Testing}

HI. There is a significant relationship between entrepreneurial behavior and entrepreneurial intention given the mediating effect of need for achievement.

Regression Weights: (Group number 1 - Default model)

\begin{tabular}{lcc|ccc}
\hline & & Estimate & P & Label \\
\hline ENTB & $<---$ & EI & .059 & .002 & \\
\hline
\end{tabular}

The basic direct relationship between the independent variable and entrepreneurial behavior is significant with $1 \%$ significance level as the pvalue $=.002 . \beta=0.059$ indicates that a unit increase in entrepreneurial intention resulted in 0.059 unit increase in entrepreneurial behavior. The mediating effect of need for achievement was not to be considered until now. Need for achievement previously had been proposed in the literature as having a positive effect on the entrepreneurial potential of an individual (Zeffane, 2013). However, until this study, mediation of need for achievement had not been proposed. Yurtkoru et al (2014) proposed a positive relationship between entrepreneurial intention and behavioral control (most likely in terms of entrepreneurship). After running the three staged mediation for need for achievement (NEDA) among entrepreneurial behavior (ENTB) and entrepreneurial intention (EI) the following AMOS findings were available. 


\section{Standardized Direct Effects - Two Tailed Significance (PC) (Group number 1 - Default model)}

\begin{tabular}{l|ccc}
\hline & EI & NEDA & ENTB \\
\hline NEDA & 0.059 & $\ldots$ & $\ldots$ \\
ENTB & 0.001 & 0.010 & $\ldots$ \\
\hline
\end{tabular}

\section{Standardized Direct Effects - Two Tailed Significance (PC) (Group} number 1 - Default model)

\begin{tabular}{cc}
\hline & EI \\
\hline ENTB & 0.010 \\
\hline
\end{tabular}

Standardized Indirect Effects - Two Tailed Significance

\begin{tabular}{|c|c|c|c|c|}
\hline & \multicolumn{2}{|c|}{ EI } & NEDA & ENTB \\
\hline NEDA & \multirow{2}{*}{\multicolumn{2}{|c|}{$\begin{array}{c}\cdots \\
0.068\end{array}$}} & $\ldots$ & $\ldots$ \\
\hline ENTB & & & $\ldots$ & $\ldots$ \\
\hline $\begin{array}{l}\text { Variables } \\
\text { (NEDA as } \\
\text { mediator) }\end{array}$ & $\begin{array}{c}\text { Direct } \\
\text { (without } \\
\text { mediation) }\end{array}$ & $\begin{array}{l}\text { Direct (with } \\
\text { mediation) }\end{array}$ & $\begin{array}{l}\text { Indirect (with } \\
\text { mediation) }\end{array}$ & Result \\
\hline $\mathrm{EI} \rightarrow \mathrm{ENTB}$ & 0.010 & 0.001 & 0.068 & No mediation \\
\hline
\end{tabular}

The results highlight that although relationships among the independent variable and mediator, and the dependent variable and mediator are significant based on the p-value, the relationship between independent and dependent variable in the presence of the mediator is not significant to the same level. This is the direct relationship, so there is no need for such mediation to be ranked as significant as had been reported in literature previously. Therefore, the alternative hypothesis is rejected.

H2. There is a significant relationship between entrepreneurial behavior and creativity given the moderating effect of self-control

Regression Weights: (Group number 1 - Default model)

\begin{tabular}{lll|c|cc}
\hline & & Estimate & P & Label \\
\hline ENTB $<---$ & CTV & 0.110 & 0.009 & \\
\hline
\end{tabular}


Regression Weights: (NO - Default model)

\begin{tabular}{ccc|c|cc}
\hline & & Estimate & P & Label \\
\hline ENTB & $<---$ & CTV & 0.253 & $* * *$ & W4_NO \\
\hline
\end{tabular}

Regression Weights: (LOW - Default model)

\begin{tabular}{cc|c|cc}
\hline & & Estimate & P & Label \\
\hline ENTB $<---$ & CTV & .251 & $* * *$ & W4_LOW \\
\hline
\end{tabular}

Regression Weights: (HIGH - Default model)

\begin{tabular}{cc|c|cc}
\hline & & Estimate & P & Label \\
\hline ENTB $<---$ & CTV & 0.235 & 0.002 & W4_HIGH \\
\hline
\end{tabular}

Creativity and entrepreneurial behavior have a significant relationship when directly compared and analyzed. The p-value $=0.009$ indicates which the direct relationship is significant at $1 \%$ significance level. $\beta=0.110$ which indicates that a one unit increase in creativity resulted in 0.110 unit increase in entrepreneurial behavior. Florida (2009) supports this fining. However, moderation on high-, low-, and no-level needs to be analyzed by using self-control as the moderator. According to van Gelderen et al. (2015), self-control moderates the relationship between intention strength (which can be considered as creativity) and taking action (entrepreneurial behavior) such that the impact of intention strength on taking action was significant when self-control was high. Our findings also provide evidence for this with $p$-value at $1 \%$ significance $(p=0.002)$ and a high beta estimate. Therefore, the alternative hypothesis is supported.

H3. There is a significant relationship between entrepreneurial behavior and entrepreneurial self-efficacy given the moderation effect of self-control

Regression Weights: (Group number 1 - Default model)

\begin{tabular}{lcc|c|cc}
\hline & & Estimate & P & Label \\
\hline ENTB & $<---$ & F1 & 0.073 & 0.005 & \\
\hline
\end{tabular}


Regression Weights: (NO - Default model)

\begin{tabular}{lcc|c|cc}
\hline & & Estimate & P & Label \\
\hline ENTB & $<--$ & F1 & 0.170 & $* * *$ & W6_NO \\
\hline
\end{tabular}

Regression Weights: (LOW - Default model)

\begin{tabular}{lcc|c|cc}
\hline & & Estimate & P & Label \\
\hline ENTB & $<--$ & F1 & 0.233 & $* * *$ & W6_LOW \\
\hline
\end{tabular}

Regression Weights: (HIGH - Default model)

\begin{tabular}{lcc|c|cc}
\hline & & Estimate & P & Label \\
\hline ENTB & $<--$ & F1 & 0.078 & 0.050 & W6_HIGH \\
\hline
\end{tabular}

This study reported a significant direct relationship between entrepreneurial self-efficacy and entrepreneurial behavior building among university students with $\mathrm{p}$-value at $1 \%$ significance level (0.005). $\beta=0.073$ demonstrates that one unit increase in entrepreneurial self-efficacy resulted in 0.073 unit increase in entrepreneurial behavior. According to Carr and Sequeira (2007), self-efficacy is positively related to entrepreneurial intent (which can be interpreted in terms of behavioral exhibition). According to van Gelderen, et al. (2015), self-control is considered an important moderator for any entrepreneurial-building relationship. Therefore in this hypothesis, moderation of self-control, whether rated as "low" or "high", is significant at $5 \%$. Therefore, the alternative hypothesis is supported and a significant relationship between entrepreneurial behavior and education is moderated through the self-control.

Regression Weights: (Group number 1 - Default model)

\begin{tabular}{lll|c|cc}
\hline & & & Estimate & P & Label \\
\hline ENTB & $<--$ & EDS & 0.095 & $* * *$ & \\
\hline
\end{tabular}

Regression Weights: (NO - Default model)

\begin{tabular}{lcc|c|cc}
\hline & & Estimate & P & Label \\
\hline ENTB & $<---$ & EDS & 0.158 & $* * *$ & W3_NO \\
\hline
\end{tabular}




\section{Regression Weights: (HIGH - Default model)}

\begin{tabular}{lcc|c|cc}
\hline & & Estimate & P & Label \\
\hline ENTB & $<---$ & EDS & 0.066 & 0.047 & W3_HIGH \\
\hline
\end{tabular}

Regression Weights: (LOW - Default model)

\begin{tabular}{ccc|ccc}
\hline & & Estimate & $\mathbf{P}$ & Label \\
\hline ENTB & $<---$ & EDS & 0.236 & $* * *$ & W3_LOW \\
\hline
\end{tabular}

According to our results, educational support has a significant relationship with entrepreneurial behavior-building of university students. Türker and Selçuk (2009) argue that the entrepreneurial knowledge and mindset of university students is dependent on educational curriculum support provided by the university. This has also been validated by our results. However, self-control was not significant in terms of the moderating effects among educational support and entrepreneurial support. There is much evidence in the literature suggesting a direct positive relationship between these two variables. Mariano et al. (2012) also proposed that educational programs shape entrepreneurial behavior-building. Therefore, the alternative hypothesis is rejected.

Regression Weights: (Group number 1 - Default model)

\begin{tabular}{lcc|c|cc}
\hline & & Estimate & P & Label \\
\hline ENTB & $<--$ & PSA & 0.012 & 0.668 & \\
\hline
\end{tabular}

Regression Weights: (no - Default model)

\begin{tabular}{|c|c|c|c|c|c|}
\hline & & & Estimate & $\mathbf{P}$ & Label \\
\hline ENTB & $<---$ & PSA & 0.151 & $* * *$ & W4_no \\
\hline
\end{tabular}

Regression Weights: (low - Default model)

\begin{tabular}{|c|c|c|c|c|c|}
\hline & & & Estimate & $\mathbf{P}$ & Label \\
\hline ENTB & $<--$ & PSA & 0.075 & 0.140 & W4_low \\
\hline
\end{tabular}

Regression Weights: (high - Default model) 


\begin{tabular}{cc|c|cc}
\hline & & Estimate & P & Label \\
\hline ENTB $<---$ & PSA & .136 & $* * *$ & W4_high \\
\hline
\end{tabular}

Yurtkoru et al. (2014) suggest a positive impact of relational support on personal attitudes building. This study also provides evidence of the mediating effect of relational support on personal attitude and entrepreneurial behavior of university students. This may be an indirect route to establish entrepreneurial behavior. Liñán and Chen (2009) propose relational support as a mediating factor on personal attitude and entrepreneurial intention. The direct relationship between entrepreneurial behavior and personal attitudes does not reach significance at a p-value of 0.668 . However, if this relationship is moderated by relational support, then it is highly significant at $1 \%$ significance value. Therefore, the alternative hypothesis is supported. $\beta=0.136$ indicate that one unit increase in personal attitudes given the moderation effect of relational support resulted in 0.136 unit increase in entrepreneurial behavior.

\section{Summary of Research Findings}

A total of 350 questionnaires were obtained from both universities. Of those, 300 questionnaires were usable. Fifty questionnaires were rejected due to missing data. $69.7 \%$ of the students in the sample from both universities acknowledged that at some point in time they considered a business setup, including an extensive feasibility study, and arrived at a point of decision. This demonstrates the environmental influence on students' considerations of the national economy in Pakistan, as well as their general preference of self-employment over a conventional job search.

$54.7 \%$ of the sample that they had been involved in team management, and working as part of a team. Entrepreneurial behavior is linked to this team management, as an entrepreneur is a team player and possesses a vision to organize his/her human resources to the best of their capabilities. This item was specific to startup team management, especially preliminarily startup initiatives that young entrepreneurs frequently undertake. Presently, business plan creation is taught in practically every business school in Pakistan. $69.7 \%$ of the students in the sample reported that they had made a business plan for some reason. This illustrates the logical reasoning ability and on-paper skills necessary to develop a concrete draft for any business venture. Behavioral testing in this regard was useful as this aspect was positive among university students. 
Thinking of a business name, with a focus on the general public or target markets is of prime importance in the process of becoming selfemployed. $63.0 \%$ of the respondents reported that they had been involved in formulating a business name. This illustrates that young entrepreneurs tend to engage in the preliminary steps and thinking processes that make a successful entrepreneur. It also captures the relative level of interest in entrepreneurship as the mental occupation of formulating a name for a business signifies positive entrepreneurial behavior.

Saving money for business is typically difficult for university students; their source of income is minimal and saving is not a priority. Generally, students interested in starting a business after they graduate expect that investment and startup capital will be provided by relational support. Consequently, only $48.0 \%$ of the students surveyed reported having saved money for the purpose of setting up a business. There are exceptions, e.g., students who started a business after earning a bachelor's degree then returned to attain a higher degree later, or students who were already in a family business and earned personal income as they attended university This is to be expected, as the sample frame mainly comprised business school students. $51.3 \%$ of the students in the sample frame responded that they have invested money into a business at some point in time. Respondents were given clarification on this item as to investment as any monetary funding for pure business, small ventures (like school stalls in a funfair), or university projects involving a practical business plan implementation. Therefore, though the responses may seem unexpected, they were in accordance with the measured aspect.

There is a significant relationship between entrepreneurial behavior and entrepreneurial intention given the mediation effect of need for achievement. The underlying issues with this proposed relationship include the direct positive relationship between entrepreneurial behavior and entrepreneurial intention that becomes less significant given the mediating effect of need for achievement. This hypothesis was rejected as need for achievement had a direct positive relationship with entrepreneurial intention and a direct positive relationship with entrepreneurial behavior but as a mediator it did not strengthen the relationship between the independent variable and the dependent variable. Need for achievement's use as mediator was not justified in this framework. (Refer to Figure 3). There is a significant relationship between entrepreneurial behavior and creativity given the moderation effect of self-control. The research results indicated that this relationship was significant as self-control proved detrimental in terms of channeling creativity for the nourishment of 
entrepreneurial behavior. Creativity had a direct positive relationship with entrepreneurial behavior, but the moderating effect of self-control between these two variables was also significant and agrees with the rationale of controlled behavioral patterns (refer to Figure 3).

There is a significant relationship between entrepreneurial behavior and entrepreneurial self-efficacy given the moderating effect of self-control. Self-efficacy in entrepreneurial behavior building was significantly supported given the moderating effect of self-control. The reasoning behind this result can be traced to the logic that personal interest and entrepreneurial intent must utilize self-control so that the apt tradeoffs are made at the ideal time for maximum benefits (refer to Figure 3). There is a significant relationship between entrepreneurial behavior and educational support given the moderation effect of self-control

The direct positive impact of educational support on behavioral makeup for entrepreneurship was articulated above. The need for selfcontrol as a moderating factor was not justified as literature exists supporting the direct relationship of entrepreneurial behavior and educational support. The relationship was proposed in this framework as an exception to the literature for the purpose of testing a probability that failed to hold true in this research (refer to Figure 3). There is a significant relationship between entrepreneurial behavior and personal attitudes given the moderation effect of relational support. Relational support is considered important for the financing of needs and possessing an attitude towards entrepreneurship alone is not enough to offset the vital role of relational support for that purpose. The moderating test was supported by the research results and relational support proved to shape entrepreneurial behavior positively (refer to Figure 3). 
Figure 2: Significant \& Non Significant relationship of Entrepreneurial Behavior with Related factors

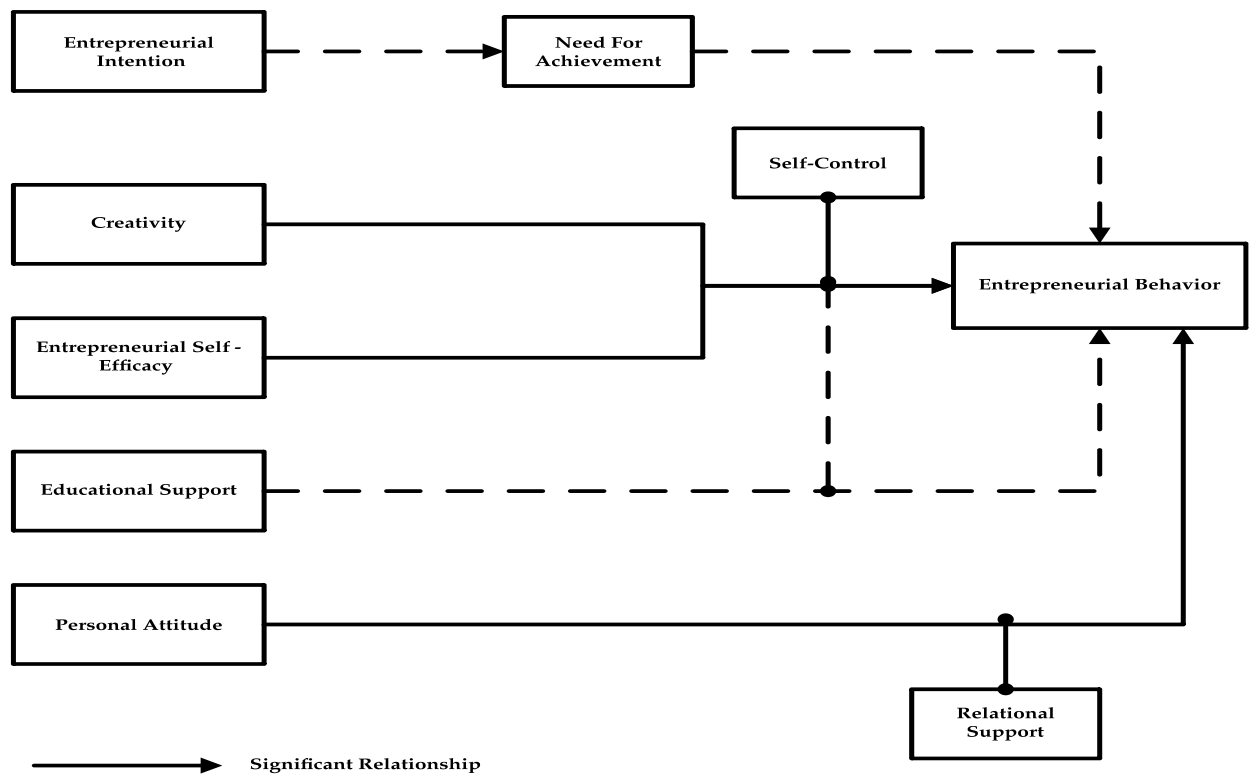

\section{Discussion and Implications}

The purpose of this study was to segment and analyze the probable factors that lead to an increase in entrepreneurial behavior among universities students. The main implication is that these young entrepreneurs have a lot of potential to contribute to the economy and national exchequer of Pakistan in the years to come through small and medium sized business ventures. This study intends to be an instrument available for use by educationists and academic policy-makers to encourage investment of time and money, to prepare young entrepreneurs for their futures. The detailed discussion to follow provides step-by-step evidence for all the relationship tests conducted in this study. This will provide further insights about important implications for governmental policy-makers and potential investors.

Entrepreneurial behavior is directed by factors such as intention, self-efficacy, creativity, and attitudes. These psychological factors have been given considerable discussion in the literature as well. The aim of this study is to match the closest derived implications from the existing literature and modern research to formulate a new theory for studying the entrepreneurial behavior of university students. 


\subsection{Implications for Managerial Educators and Policy-Makers}

This research was conducted with the purpose of identifying the factors that shape behavior of students in favor of entrepreneurship. The significant benefit of such behavior has long-lasting implications in terms of the opportunity landscape that might emerge as a result. Pakistan is considered by many to be a land of opportunities. Taking this view forward, the managerial educators that devise, design, and implement curriculum in universities, schools, and colleges must be made aware of the countless benefits that young entrepreneurs can bring to the national GDP and exchequer. However, this preparation should not be confined to business and commerce students only. Students from all disciplines should be provided with basic training and clear concepts about entrepreneurship.

The research concluded that entrepreneurial behavior is brought about by the fostering of basic intention, self-efficacy, educational support, creativity in thinking, and personal attitude towards entrepreneurial activities. Therefore, it is important for teachers, scholars, and writers of managerial sciences to promote the significance of each of these components among young students, especially at the university level. Regular workshops discussing the findings of new research in student entrepreneurship must be conducted among university students so they may be well-equipped and aware of the latest national and international entrepreneurial landscape. This would necessitate a major opportunity cost analysis, and students could make an informed choice between selfemployment and a conventional job search. As careful analysis of the useful concepts in the existing literature was the intention of this research, so too should managerial educators follow suit, utilizing existing and current research to create a modern entrepreneurial curriculum. Awareness about entrepreneurial success stories over time should also form part of curriculum.

Policy-makers include government bodies, universities' board of directors, and publication associations. Their action on policy matters dictates general public behavior and reactions. In Pakistan, the Prime Minister's recent funding for small-scale business setups should be considered a substantial step towards promoting young entrepreneurship across the country. Government at each level needs to annually allocate funds for this type of education as student entrepreneurship has become a global phenomenon. Funding should also be made available for practical implementation of business plans made by university students still in the process of completing their degree. Local, provincial, and federal 
governments need to work in collaboration with major universities to create appropriate curricula for entrepreneurship education and support entrepreneurial behavior by opening vocational centers at university campuses. This holistic solution creates awareness for student entrepreneurship across the country until such a time that a multiplier effect is present.

Universities should sponsor and host business plan competitions within and between various universities, and award funds for the bestranked plans. Sponsorships and endorsements must be acquired from major corporate organizations like banks to promote the culture of student entrepreneurship. Publications bodies should be encouraged to hold seminars, include articles, and report on presentations on entrepreneurship. This would have the effect of introducing novel literature and fresh perspectives on student entrepreneurship. New theories of planned behavior and attitudes testing must be a prominent part of the call for journal papers every year. National events must be held to generalize entrepreneurship among the public at large. Each of these propositions has the prime intent of promoting and nourishing student entrepreneurship, as our country continues to lag behind other countries in this area. Those nations made the sacrifices necessary to achieve what they have. This research aims to increase economic and social development of Pakistan.

\subsection{Recommendations for Future Research}

This study has provided important findings on and the implications of student entrepreneurship. Based on the discussions so far presented, concluding recommendations for future research are proposedThe mediating role of need for achievement should form part of future research initiatives, as this factor has been tested extensively directly in relation to entrepreneurial intention and behavior, but its mediating effect must be better understood and measured through the devising of new research scales and analytical models.

Self-control as a moderator has not yet been tested with self-efficacy and creativity variables impacting entrepreneurial behavior, in particular. Scope currently exists in the literature to define levels of self-control and their relative impact on the behavior of university students. (Moderation models are rare in the literature.)Personal attitudes break down into specific components, such as emotions, aptitude, introversion, and extroversion, must form part of future studies to better investigate the impact of a student's general attitude on behavioral outcomes. This is 
significant as previous research studies provide a holistic view of personal attitude, rather than its component parts.

Relational support is an important determinant of entrepreneurial behavior, and it can have an important moderating impact on the relationship between various factors and entrepreneurial behavior. Therefore, relational support must be separated further into family support and acquaintances support in order to analyze in detail how important relationship-building is for complementing entrepreneurial initiatives. Diversity in independent variables selection is not readily evident in existing literature. Vast scope exists that can be exploited to formulate a diverse range of independent variables effecting overall entrepreneurial behavior of university students.

A limitation of this study was that the ratio of male and female participants in the survey result was not equal. This was out of the scope of this specific study, but future research on this theme should incorporate the significant area of gender study, as well.

Socio-economic factors are not well represented in the existing literature, as there are no studies examining students' responses from lower- and higher-end universities (e.g., those in remote areas, those in city centers, etc.). Comparison studies must be conducted to analyze the variation of behavior across certain segments of students in various cities, as well as areas within Pakistan and outside the country. 


\section{References}

Ahmed, I., Nawaz, M. M., Ahmad, Z., Shaukat, M. Z., Usman, A., Rehman, W. U., \& Ahmed, N. (2010). Determinants of students' entrepreneurial career intentions: Evidence from business graduates. European Journal of Social Sciences, 15(2), 14-22.

Ajzen, I. (1991). Theory of planned behaviour. Organizational Behavior and Human Decision Processes, 50. 179-211.

Alsos, G. A., \& Kolvereid, L. (1998). The business gestation process of novice, serial, and parallel business founders. Entrepreneurship Theory and Practice, 22(4), 101-114.

Aslam, T. M., Awan, A. S., \& Khan, T. M. (2012). An Empirical study of family background and entrepreneurship as career selection among university students of Turkey and Pakistan. International Journal of Business and Social Science, 3(15), 118-123.

Athayde, R. (2009). Measuring enterprise potential in young people. Entrepreneurship Theory and Practice, 33(2), 481-500.

Carr, J. C., \& Sequeira, J. M. (2007). Prior family business exposure as intergenerational influence and entrepreneurial intent: A theory of planned behavior approach. Journal of Business Research, 60(10), 1090-1098.

Carter, N. M., Gartner, W. B., Shaver, K. G., \& Gatewood, E. J. (2003). The career reasons of nascent entrepreneurs. Journal of Business Venturing, 18(1), 13-39.

Carter, S., \& Ram, M. (2003). Reassessing portfolio entrepreneurship. Small Business Economics, 21(4), 371-380.

Couto, C. P., Mariano, S. R. H., \& Mayer, V. F. (2014). Entrepreneurial intention in Brazil: the challenge in using international measurement. Revista Alcance, 20(4 (Out-Dez)), 447-459.

Crook, T.R., Shook, C.L., Morris, M.L., \& Madden, T.M. (2010). Are we there yet? An assessment of research design and construct measurement practices in entrepreneurship research. Organizational Research Methods, 13(1), 192-206. 
CUNNINGHAM, J. B.; LISCHERON, J. Defining Entrepreneurship. Journal of Small Business Management, 1991, v. 29, p.45-61.

DRENNAN, J; KENNEDY, J; RENFROW, P. Impact of childhood experiences on the development of entrepreneurial intention. Entrepreneurship and Innovation, 2005, v. 6, p. 231-238.

Dwyer, A. L., \& Cummings, A. L. (2001). Stress, self-efficacy, social support, and coping strategies in university students. Canadian Journal of Counselling.

Fillis, I. and Rentscheler, R. (2010). The role of creativity in entrepreneurship. Journal of Enterprising Culture, 18 (1), 49-81.

Florida, R. (2009) "Entrepreneurship, creativity, and regional growth". The Emergence of Entrepreneurship Policy, In Hart, D. M. (Ed.), Cambridge, Cambridge University Press, pp. 39-59

Ford, J. K., MacCallum, R. C., \& Tait, M. (1986). The application of exploratory factor analysis in applied psychology: A critical review and analysis. Personnel Psychology, 39(2), 291-314.

Gaddam, S. (2007). A conceptual analysis of factors influencing entrepreneurship behaviour and actions. The Icfaian Journal of Management Research, 6(11), 46-63.

Gartner, W. B., Carter, N. M., \& Reynolds, P. D. (2010). Entrepreneurial behavior: Firm organizing processes. In Handbook of Entrepreneurship Research (pp. 99-127). Springer, New York, NY.

Gedik, Ş., Miman, M., \& Kesici, M. S. (2015). Characteristics and attitudes of entrepreneurs towards entrepreneurship. Procedia-Social and Behavioral Sciences, 195, 1087-1096.

Ghasemi, F., Rastegar, A., Jahromi, R. G., \& Marvdashti, R. R. (2011). The relationship between creativity and achievement motivation with high school students' entrepreneurship. Procedia-Social and Behavioral Sciences, 30, 1291-1296.

Gielnik, M. M., Frese, M., Kahara-Kawuki, A., Katono, I. W., Kyejjusa, S., Ngoma, M.,. \& Dlugosch, T. J. (2015). Action and action-regulation in entrepreneurship: evaluating a student training for promoting entrepreneurship. Academy of Management Learning $\mathcal{E}$ Education, 14(1), 69-94. 
Gross, J.J., Richards, J.M., John, O.P. (2006). Emotion regulation in everyday life. In: Snyder,

Ishiguro, J. (2015). What influences entrepreneurial career choice?: An exploratory analysis of the Sally Caird's Get2 for Japanese high school students. Academy of Entrepreneurship Journal, 21(1), 44.

KARIMI, S.; CHIZARI; BIEMANS, H. J. A.; MULDER M. Entrepreneurship Education in Iranian Higher Education: The Current State and Challenges. European. Journal of Scientific Research ISSN, 1450216X, v. 48, n. 1, pp. 35-50, 2010.

Kautonen, T., van Gelderen, M., \& Tornikoski, E. T. (2013). Predicting entrepreneurial behavior: A test of the theory of planned behavior. Applied Economics, 45(6): 697-707.

Kautonen, T., Hatak, I., Kibler, E., \& Wainwright, T. (2015). Emergence of entrepreneurial behaviour: The role of age-based self-image. Journal of Economic Psychology, 50, 41-51.

Kraaijenbrink, J., Bos, G., \& Groen, A. (2009). What do students think of the entrepreneurial support given by their universities?. International Journal of Entrepreneurship and Small Business, 9(1), 110-125.

Krueger Jr, N. F., Reilly, M. D., \& Carsrud, A. L. (2000). Competing models of entrepreneurial intentions. Journal of business venturing, 15(5-6), 411-432.

Krueger, N. F. (2008). Entrepreneurial resilience: Real \& perceived barriers to implementing entrepreneurial intentions. Available at SSRN 1155269.

Liñán, F., (2008). Skill and value perceptions: how do they affect entrepreneurial intentions?. International Entrepreneurship and Management Journal, 4(3), 257-272.

Liñán, F., \& Chen, Y. W. (2009). Development and cross-cultural application of a specific instrument to measure entrepreneurial intentions. Entrepreneurship Theory and Practice, 33(3), 593-617.

Maslach, C., Jackson, S. E., \& Leiter, M. P. (1996). MBI: Maslach burnout inventory. Sunnyvale (CA): CPP, Incorporated. 
McGee, J. E., Peterson, M., Mueller, S.L., \& Sequeira, J.M. (2009). Entrepreneurial self-efficacy: Refining the measure. Entrepreneurship Theory \& Practice 33. 965-88.

Moruku, R. K. (2013). Does entrepreneurial orientation predict entrepreneurial behaviour?. International Journal of Entrepreneurship, 17,41 .

Mullen, M.R., Budeva, D.G., \& Doney, P.M. (2009). Research methods in the leading small business-entrepreneurship journals: A critical review with recommendations for future research. Journal of Small Business Management, 47(3)

Niţu, R. A., \& Feder, E. S. (2012). Entrepreneurial behaviour consequences on small and medium-sized firms' innovation. Theoretical and Applied Economics, 7(7), 85.

Nunnally, J. C. (1978). Psychometric theory. New York: McGraw-Hill.

Okhomina, D. A. (2010). The relationship between personality traits and entrepreneurial behavior and the moderating role of a supportive environment. International Journal of Business $\mathcal{E}$ Economics Perspectives, 5(1), 139-154.

Ozgul, U., \& Kunday, O. (2015). Conceptual development of academic entrepreneurial intentions scale. Procedia-Social and Behavioral Sciences, 195, 881-887.

Rauch, A., \& Hulsink, W. (2015). Putting entrepreneurship education where the intention to act lies: An investigation into the impact of entrepreneurship education on entrepreneurial behavior. Academy of management learning $\mathcal{E}$ education, 14(2), 187-204.

Reynolds, P. D., Hay, M., \& Camp, S. M. (1999). Global entrepreneurship monitor: 1999 executive report.

Saeed, S., Muffatto, M., \& Yousafzai, S. (2014). A multi-level study of entrepreneurship education among Pakistani university students. Entrepreneurship Research Journal, 4(3), 297-321.

Schmidt, J. J., Soper, J. C., \& Bernaciak, J. (2012). Creativity in the entrepreneurship program: A survey of directors of award winning programs. In Academy of Entrepreneurship (Vol. 18, No. 1, p. 51). 
Schlaegel, D., \& Koenig, M. (2011). Determinants of entrepreneurial intent: A meta-analytic test and integration of competing models. GForum, Zuerich, November 2-4.

Segal, G., Borgia, D. and Schoenfeld, J. (2007). The motivation to become an entrepreneur. International Journal of Entrepreneurial Behavior and Research 1(1):42-57.

Segal, G., Schoenfeld, J., \& Borgia, D. (2007). Which classroom-related activities enhance students'entrepreneurial interests and goals?: A social cognitive career theory perspective. Academy of Entrepreneurship Journal, 13(2), 79.

Sial, M. S., \& Chudry, A. (2011). What factors are responsible for low inclination towards entrepreneurship in the business students of Islamabad?. Journal of Commerce (22206043), 3(4).

Short, J.C., Ketchen, D.J., Combs, J.G., \& Ireland, R.D. (2010). Research methods in entrepreneurship: Opportunities and challenges. Organizational Research Methods, 13(1), 6-15

Souitaris, V., Zerbinati, S., \& Al-Laham, A. (2007). Do entrepreneurship programmes raise entrepreneurial intention of science and engineering students? The effect of learning, inspiration and resources. Journal of Business venturing, 22(4), 566-591.

Tangney, J.P., Baumeister, R.F., Boone, A.L., (2004). High self-control predicts good adjustment, less pathology, better grades, and interpersonal success. J. Pers. 72, 271-324.

Tanveer, M. A., Gillani, U. A., Rizvi, S., Latif, M., Maqbool, H., \& Rizwan, M. (2011). Barriers for business students in becoming an entrepreneur in Pakistan. IOSR Journal of Business and Management, 74-82.

Tanveer, M. A., Shafique, O., Akbar, S., \& Rizvi, S. (2013). Intentions of business graduate and undergraduate to become entrepreneur: A study from Pakistan. Journal of Basic and Applied Science, 3(1), 718-725.

Townsend, D. M., Busenitz, L.W., and Arthurs, J.D. (2010). To start or not to start: Outcome and ability expectations in the decision to start a new venture. Journal of Business Venturing 25, 192-202. 
Turker, D., \& Sonmez Selçuk, S. (2009). Which factors affect entrepreneurial intention of university students?. Journal of European Industrial Training, 33(2), 142-159.

Usaci, D. (2015). Predictors of professional entrepreneurial intention and behavior in the educational field. Procedia-Social and Behavioral Sciences, 187, 178-183

Valliere, D. (2015). An effectuation measure of entrepreneurial intent. Procedia-Social and Behavioral Sciences, 169, 131-142.

Van Gelderen, M., Kautonen, T., \& Fink, M. (2015). From entrepreneurial intentions to actions: Self-control and action-related doubt, fear, and aversion. Journal of Business Venturing, 30(5), 655-673.

Yar Hamidi, D., Wennberg, K. and Berglund, H. (2008). Creativity in entrepreneurship education. Journal of Small Business and Enterprise Development, 15(2) 304-320.

Yurtkoru, E. S., Kuşcu, Z. K., \& Doğanay, A. (2014). Exploring the antecedents of entrepreneurial intention on Turkish university students. Procedia-Social and Behavioral Sciences, 150, 841-850.

Zain, Z. M., Akram, A. M., \& Ghani, E. K. (2010). Entrepreneurship intention among Malaysian business students. Canadian Social Science, 6(3), 34-44.

Zapkau, F. B., Schwens, C., Steinmetz, H., \& Kabst, R. (2015). Disentangling the effect of prior entrepreneurial exposure on entrepreneurial intention. Journal of Business Research, 68(3), 639-653.

Zeffane, R. (2013). Need for achievement, personality and entrepreneurial potential: A study of young adults in the United Arab Emirates. Journal of Enterprising Culture, 21(01), 75-105. 


\section{Appendix}

\section{Research Questionnaire}

Please use the given rating scale to indicate the extent to which you agree with the following statements.

\begin{tabular}{|c|c|c|c|c|c|}
\hline $\begin{array}{l}\text { ENTREPRENEURIAL } \\
\text { INTENTION }\end{array}$ & $\begin{array}{l}\text { Strongly } \\
\text { Disagree }\end{array}$ & Disagree & Neutral & Agree & $\begin{array}{l}\text { Strongly } \\
\text { Agree }\end{array}$ \\
\hline $\begin{array}{l}\text { I am determined to create a } \\
\text { firm in the future. }\end{array}$ & 1 & 2 & 3 & 4 & 5 \\
\hline $\begin{array}{l}\text { I have very seriously thought } \\
\text { of starting a firm. }\end{array}$ & 1 & 2 & 3 & 4 & 5 \\
\hline $\begin{array}{l}\text { I am determined to create a } \\
\text { firm in the future. }\end{array}$ & 1 & 2 & 3 & 4 & 5 \\
\hline $\begin{array}{l}\text { I will make every effort to } \\
\text { start and run my own firm. }\end{array}$ & 1 & 2 & 3 & 4 & 5 \\
\hline \multicolumn{6}{|l|}{$\begin{array}{l}\text { SELF } \\
\text { CONTROL }\end{array}$} \\
\hline $\begin{array}{l}\text { It is difficult for me to get rid } \\
\text { of bad habits }\end{array}$ & 1 & 2 & 3 & 4 & 5 \\
\hline $\begin{array}{l}\text { Pleasant and fun things } \\
\text { sometimes prevent me from } \\
\text { getting work done }\end{array}$ & 1 & 2 & 3 & 4 & 5 \\
\hline $\begin{array}{l}\text { I have difficulties } \\
\text { concentrating }\end{array}$ & 1 & 2 & 3 & 4 & 5 \\
\hline $\begin{array}{l}\text { Sometimes I cannot prevent } \\
\text { myself doing things I know } \\
\text { are wrong }\end{array}$ & 1 & 2 & 3 & 4 & 5 \\
\hline \multicolumn{6}{|l|}{ RELATIONAL SUPPORT } \\
\hline $\begin{array}{l}\text { If I decided to be an } \\
\text { entrepreneur, my close } \\
\text { network (from work, school, } \\
\text { and neighborhood) supports } \\
\text { me. }\end{array}$ & 1 & 2 & 3 & 4 & 5 \\
\hline $\begin{array}{l}\text { If I decided to be an } \\
\text { entrepreneur, my friends } \\
\text { support me. }\end{array}$ & 1 & 2 & 3 & 4 & 5 \\
\hline $\begin{array}{l}\text { If I decided to be an } \\
\text { entrepreneur, my family } \\
\text { members support me. }\end{array}$ & 1 & 2 & 3 & 4 & 5 \\
\hline
\end{tabular}

Please use the given rating scale to indicate the extent to which you agree with the following statements. 


\begin{tabular}{|c|c|c|c|c|c|}
\hline $\begin{array}{l}\text { PERSONAL } \\
\text { ATTITUDE }\end{array}$ & $\begin{array}{l}\text { Strongly } \\
\text { Disagree }\end{array}$ & Disagree & Neutral & Agree & $\begin{array}{l}\text { Strongly } \\
\text { Agree }\end{array}$ \\
\hline $\begin{array}{l}\text { Being an entrepreneur would } \\
\text { entail great satisfactions for } \\
\text { me. }\end{array}$ & 1 & 2 & 3 & 4 & 5 \\
\hline $\begin{array}{l}\text { Among various options, I } \\
\text { would rather be an } \\
\text { entrepreneur. }\end{array}$ & 1 & 2 & 3 & 4 & 5 \\
\hline $\begin{array}{l}\text { Being an entrepreneur } \\
\text { implies more advantages } \\
\text { than disadvantages to me. }\end{array}$ & 1 & 2 & 3 & 4 & 5 \\
\hline $\begin{array}{l}\text { If I had the opportunity and } \\
\text { resources, I'd like to start a } \\
\text { firm. }\end{array}$ & 1 & 2 & 3 & 4 & 5 \\
\hline \multicolumn{6}{|l|}{ CREATIVITY } \\
\hline $\begin{array}{l}\text { Other people think that I'm } \\
\text { always making changes and } \\
\text { trying out new ideas. }\end{array}$ & 1 & 2 & 3 & 4 & 5 \\
\hline $\begin{array}{l}\text { Sometimes people find my } \\
\text { ideas unusual. }\end{array}$ & 1 & 2 & 3 & 4 & 5 \\
\hline $\begin{array}{l}\text { Sometimes I have so many } \\
\text { ideas that I feel pressurized. }\end{array}$ & 1 & 2 & 3 & 4 & 5 \\
\hline $\begin{array}{l}\text { At work, I often take over } \\
\text { projects and steer them my } \\
\text { way without worrying about } \\
\text { what other people think. }\end{array}$ & 1 & 2 & 3 & 4 & 5 \\
\hline $\begin{array}{l}\text { If I had a good idea for } \\
\text { making some money, I } \\
\text { would be willing to invest } \\
\text { my time and borrow money } \\
\text { to enable me to do it. }\end{array}$ & 1 & 2 & 3 & 4 & 5 \\
\hline
\end{tabular}

Please use the given rating scale to indicate the extent to which you agree with the following statements.

\begin{tabular}{lccccc}
\hline $\begin{array}{l}\text { NEED FOR } \\
\text { ACHIEVEMENT }\end{array}$ & $\begin{array}{c}\text { Strongly } \\
\text { Disagree }\end{array}$ & Disagree & Neutral & Agree & $\begin{array}{c}\text { Strongly } \\
\text { Agree }\end{array}$ \\
\hline $\begin{array}{l}\text { Hard work is something I } \\
\text { like to avoid }\end{array}$ & 1 & 2 & 3 & 4 & 5 \\
$\begin{array}{l}\text { I believe I would enjoy } \\
\text { having authority over other } \\
\text { people }\end{array}$ & 1 & 2 & 3 & 4 & 5 \\
$\begin{array}{l}\text { I would like an important job } \\
\text { where people would look up } \\
\text { to me }\end{array}$ & 1 & 2 & 3 & 4 & 5 \\
\end{tabular}




\begin{tabular}{|c|c|c|c|c|c|c|}
\hline \multicolumn{7}{|l|}{ EDUCATIONAL SUPPORT } \\
\hline $\begin{array}{l}\text { The education in university } \\
\text { encourages me to develop } \\
\text { creative ideas for being an } \\
\text { entrepreneur. }\end{array}$ & 1 & 2 & & 3 & 4 & 5 \\
\hline $\begin{array}{l}\text { My university develops my } \\
\text { entrepreneurial skills and } \\
\text { abilities. }\end{array}$ & 1 & 2 & & 3 & 4 & 5 \\
\hline $\begin{array}{l}\text { My university provides the } \\
\text { necessary knowledge about } \\
\text { entrepreneurship. }\end{array}$ & 1 & 2 & & 3 & 4 & 5 \\
\hline \multicolumn{7}{|l|}{$\begin{array}{l}\text { Please use the "Yes" \& "No" } \\
\text { Options to indicate the } \\
\text { extent to which you agree } \\
\text { with the following } \\
\text { statements. }\end{array}$} \\
\hline $\begin{array}{l}\text { Spent a lot of time thinking } \\
\text { about starting a business? }\end{array}$ & & & \multicolumn{2}{|c|}{ YES } & \multicolumn{2}{|c|}{$\mathrm{NO}$} \\
\hline Organized a start-up team? & & & \multicolumn{2}{|c|}{ YES } & \multicolumn{2}{|c|}{$\mathrm{NO}$} \\
\hline Prepared a business plan? & & & \multicolumn{2}{|c|}{ YES } & \multicolumn{2}{|c|}{$\mathrm{NO}$} \\
\hline Selected a business name? & & & \multicolumn{2}{|c|}{ YES } & \multicolumn{2}{|c|}{$\mathrm{NO}$} \\
\hline $\begin{array}{l}\text { Saved money to invest in a } \\
\text { business? }\end{array}$ & & & \multicolumn{2}{|c|}{ YES } & \multicolumn{2}{|c|}{ NO } \\
\hline $\begin{array}{l}\text { Invested your own money in } \\
\text { a business? }\end{array}$ & & & \multicolumn{2}{|c|}{ YES } & \multicolumn{2}{|c|}{$\mathrm{NO}$} \\
\hline $\begin{array}{l}\text { Please use the given rating } \\
\text { scale to indicate the extent } \\
\text { to which you are confident } \\
\text { about the following } \\
\text { statements. }\end{array}$ & & $\begin{array}{l}\text { Very } \\
\text { little } \\
\text { confide } \\
\text { nce }\end{array}$ & $\begin{array}{c}\text { Some } \\
\text { Confide } \\
\text { nce }\end{array}$ & Neutral & $\begin{array}{c}\text { Confide } \\
n t\end{array}$ & $\begin{array}{l}\text { complet } \\
\text { e } \\
\text { confide } \\
\text { nce }\end{array}$ \\
\hline $\begin{array}{l}\text { Work long hours in my } \\
\text { business }\end{array}$ & & 1 & 2 & 3 & 4 & 5 \\
\hline $\begin{array}{l}\text { Save or personally } \\
\text { accumulate the necessary } \\
\text { capital to fund my business }\end{array}$ & & 1 & 2 & 3 & 4 & 5 \\
\hline $\begin{array}{l}\text { Recognize a business } \\
\text { opportunity before others do }\end{array}$ & & 1 & 2 & 3 & 4 & 5 \\
\hline $\begin{array}{l}\text { Prepare projected (pro- } \\
\text { forma) financial statements } \\
\text { (e.g. balance sheets) without } \\
\text { assistance }\end{array}$ & & 1 & 2 & 3 & 4 & 5 \\
\hline $\begin{array}{l}\text { Identify the need for a new } \\
\text { product or service }\end{array}$ & & 1 & 2 & 3 & 4 & 5 \\
\hline $\begin{array}{l}\text { Get others to identify with } \\
\text { and believe in my vision \& } \\
\text { plans for a new business }\end{array}$ & & 1 & 2 & 3 & 4 & 5 \\
\hline
\end{tabular}


Table 1 Findings of Research on Student Entrepreneurship in Pakistan

\begin{tabular}{|c|c|c|c|c|c|}
\hline $\begin{array}{l}\text { Student } \\
\text { Entrepreneurship }\end{array}$ & $\begin{array}{l}\text { Variables } \\
\text { Studied }\end{array}$ & Results & Sample Size & Sector/City & Author \\
\hline $\begin{array}{l}\text { 1) Dimension: } \\
\text { Family } \\
\text { Background \& } \\
\text { Career Selection }\end{array}$ & $\begin{array}{l}\text { Personal } \\
\text { Attitude, Social } \\
\text { Norms, Perceived } \\
\text { Behavioral } \\
\text { control, } \\
\text { Entrepreneurship } \\
\text { Education and } \\
\text { Entrepreneurial } \\
\text { Intention }\end{array}$ & $\begin{array}{l}\text { Personal } \\
\text { attitudes and } \\
\text { behavioral } \\
\text { control } \\
\text { significantly } \\
\text { impact } \\
\text { entrepreneurial } \\
\text { intention. }\end{array}$ & $\begin{array}{l}150 \text { Pakistani } \\
\text { university } \\
\text { Students }\end{array}$ & Pakistan & $\begin{array}{l}\text { Aslam et } \\
\text { al. (2012) }\end{array}$ \\
\hline $\begin{array}{l}\text { 2)Dimension: } \\
\text { Intention of } \\
\text { Business Graduate } \\
\text { and } \\
\text { Undergraduate to } \\
\text { be an } \\
\text { entrepreneur }\end{array}$ & $\begin{array}{l}\text { Family } \\
\text { background, } \\
\text { gender, education } \\
\text { and role of } \\
\text { university }\end{array}$ & $\begin{array}{l}\text { Graduates have } \\
\text { a clear intention } \\
\text { for job as } \\
\text { compared to } \\
\text { self- } \\
\text { employment }\end{array}$ & $\begin{array}{l}114 \text { students of } \\
\text { The Islamia } \\
\text { University of } \\
\text { Bahawalpur }\end{array}$ & Bahawalpur & $\begin{array}{l}\text { Tanveer } \\
\text { et al. } \\
2013\end{array}$ \\
\hline $\begin{array}{l}\text { 3)Dimension: } \\
\text { Barriers for } \\
\text { Business Students } \\
\text { in Becoming an } \\
\text { Entrepreneur }\end{array}$ & $\begin{array}{l}\text { Subjective Norms } \\
\text { \& entrepreneurial } \\
\text { intention }\end{array}$ & $\begin{array}{l}\text { Weak financial } \\
\text { resources \& } \\
\text { weak economic } \\
\text { conditions } \\
\text { discourage } \\
\text { entrepreneurial } \\
\text { intentions }\end{array}$ & $\begin{array}{l}114 \text { students of } \\
\text { The Islamia } \\
\text { University of } \\
\text { Bahawalpur }\end{array}$ & Bahawalpur & $\begin{array}{l}\text { Tanveer } \\
\text { et al. } \\
2011\end{array}$ \\
\hline $\begin{array}{l}\text { 4)Dimension: Low } \\
\text { inclination } \\
\text { towards } \\
\text { entrepreneurship } \\
\text { of business } \\
\text { students of } \\
\text { Islamabad }\end{array}$ & $\begin{array}{l}\text { Support, Risk } \\
\text { tolerance, } \\
\text { innovation \& } \\
\text { intention }\end{array}$ & $\begin{array}{l}\text { Entrepreneurial } \\
\text { orientation is } \\
\text { very low among } \\
\text { the business } \\
\text { students due to } \\
\text { lack of interest }\end{array}$ & $\begin{array}{l}20 \text { students } \\
\text { each from } \\
\text { various } \\
\text { universities }\end{array}$ & Islamabad & $\begin{array}{l}\text { Sial and } \\
\text { Chudry } \\
(2011)\end{array}$ \\
\hline $\begin{array}{l}\text { 5)Dimension: } \\
\text { Entrepreneurship } \\
\text { Education among } \\
\text { Pakistani } \\
\text { University } \\
\text { Students }\end{array}$ & $\begin{array}{l}\text { self-control, } \\
\text { creativity and } \\
\text { subjective norms } \\
\text { \& Intention }\end{array}$ & $\begin{array}{l}\text { Entrepreneurial } \\
\text { intention is } \\
\text { significantly } \\
\text { driven by } \\
\text { underlining } \\
\text { factors like self- } \\
\text { control and } \\
\text { subjective } \\
\text { norms }\end{array}$ & $\begin{array}{l}805 \\
\text { undergraduate } \\
\text { students in } \\
\text { universities in } \\
\text { Pakistan }\end{array}$ & Pakistan & $\begin{array}{l}\text { Saeed et } \\
\text { al. (2014) }\end{array}$ \\
\hline
\end{tabular}


Empirical Evidence from Pakistan

Table 2: Instrument Description

\begin{tabular}{llcc}
\hline Instrument & \multicolumn{1}{c}{ Creators } & Year & No. Of Items \\
\hline Entrepreneurial Intention & Yurtkoru et al. & 2014 & 4 \\
Self- Control & Van Gelderen et al. & 2015 & 4 \\
Relational Support & Yurtkoru et al. & 2014 & 3 \\
Personal Attitude & Yurtkoru et al. & 2014 & 4 \\
Entrepreneurial Behavior & Rauch \& Hulsink & 2015 & 6 \\
Entrepreneurial self-efficacy & Carr \& Sequeira & 2007 & 6 \\
Creativity & Ishiguro & 2015 & 5 \\
Need for achievement & Carter et al. & 2003 & 3 \\
Educational Support & Yurtkoru et al. & 2014 & 3 \\
\hline
\end{tabular}

Table 3: Descriptive Statistics

\begin{tabular}{lccc}
\hline & Mean & Std. Deviation & N \\
\hline Entrepreneurial Intention & 3.6683 & .98313 & 300 \\
Self-Control & 3.0258 & .79791 & 300 \\
Relational Support & 3.7788 & .70361 & 300 \\
Personal Attitudes & 3.8333 & .68894 & 300 \\
Creativity & 3.5473 & .58501 & 300 \\
Need for achievement & 3.4020 & .70880 & 300 \\
Educational Support & 3.8121 & .79119 & 300 \\
Entrepreneurial Self Efficacy & 3.6023 & .69843 & 300 \\
\hline
\end{tabular}


Table 4: Correlations

\begin{tabular}{|c|c|c|c|c|c|c|c|c|c|c|}
\hline & & $\begin{array}{c}\text { ENTI } \\
\text { NT }\end{array}$ & SC & RS & PA & CRET & $\begin{array}{c}\text { NFAC } \\
\text { H }\end{array}$ & ES & EB & $\begin{array}{c}\text { ENTS } \\
\text { F }\end{array}$ \\
\hline $\begin{array}{l}\text { ENTI } \\
\text { NT }\end{array}$ & $\begin{array}{l}\text { Pearson } \\
\text { Correlation }\end{array}$ & 1 & -.072 & $.333^{* * *}$ & $.549^{* *}$ & $.417^{* *}$ & $.117^{*}$ & $.302^{* * *}$ & $.405^{* *}$ & $.499^{* *}$ \\
\hline SC & $\begin{array}{l}\text { Pearson } \\
\text { Correlation }\end{array}$ & -.072 & 1 & -.023 & .035 & -.019 & $.239^{* *}$ & $-.173^{* *}$ & $-.258^{* *}$ & -.064 \\
\hline RS & $\begin{array}{l}\text { Pearson } \\
\text { Correlation }\end{array}$ & $.333^{* *}$ & -.023 & 1 & $.509^{* * *}$ & $.348^{* *}$ & $.158^{* *}$ & $.371^{* *}$ & $.313^{* * *}$ & $.317^{* *}$ \\
\hline PA & $\begin{array}{l}\text { Pearson } \\
\text { Correlation }\end{array}$ & $.549^{* *}$ & .035 & $.509^{* * *}$ & 1 & $.437^{* *}$ & $.201^{* * *}$ & $.319^{* * *}$ & $.307^{* *+}$ & $.407^{* * *}$ \\
\hline CRET & $\begin{array}{l}\text { Pearson } \\
\text { Correlation }\end{array}$ & $.417^{* *}$ & -.019 & $.348^{* *}$ & $.437^{* *+}$ & 1 & $.259^{* *}$ & $.294^{* *}$ & $.371^{* *}$ & $.322^{* *}$ \\
\hline $\begin{array}{l}\mathrm{NFA} \\
\mathrm{CH}\end{array}$ & $\begin{array}{l}\text { Pearson } \\
\text { Correlation }\end{array}$ & $.117^{*}$ & $.239^{* * *}$ & $.158^{* * *}$ & $.201^{* *}$ & $.259^{* * *}$ & 1 & $.166^{* *}$ & .088 & $.206^{* * *}$ \\
\hline ES & $\begin{array}{l}\text { Pearson } \\
\text { Correlation }\end{array}$ & $.302^{* *}$ & $-.173^{* *}$ & $.371^{* *}$ & $.319^{* *}$ & $.294^{* * *}$ & $.166^{* *}$ & 1 & $.310^{* * *}$ & $.265^{* *}$ \\
\hline EB & $\begin{array}{l}\text { Pearson } \\
\text { Correlation }\end{array}$ & $.405^{* *}$ & $-.258^{* *}$ & $.313^{* * *}$ & $.307^{* *}$ & $.371^{* *}$ & .088 & $.310^{* *}$ & 1 & $.362^{* *}$ \\
\hline $\begin{array}{l}\text { ENTS } \\
\text { F }\end{array}$ & $\begin{array}{l}\text { Pearson } \\
\text { Correlation }\end{array}$ & $.499^{* *}$ & -.064 & $.317^{* *+}$ & $.407^{* *}$ & $.322^{* * *}$ & $.206^{* *}$ & $.265^{* *}$ & $.362^{* * *}$ & 1 \\
\hline
\end{tabular}

**. Correlation is significant at the 0.01 level (1-tailed).

* Correlation is significant at the 0.05 level (1-tailed).

Table 5: Confirmatory Factor Analysis Table

\begin{tabular}{lcccc}
\hline Variables & $\begin{array}{c}\text { Factor Loading } \\
\text { Range }\end{array}$ & CR & AVE & DV \\
\hline Entrepreneurial Self Efficacy & $0.54-0.76$ & 0.838 & 0.466 & 0.683 \\
Entrepreneurial Intention & $0.75-0.92$ & 0.923 & 0.752 & 0.867 \\
Personal Attitudes & $0.62-0.85$ & 0.827 & 0.548 & 0.740 \\
Educational Support & $0.63-0.83$ & 0.743 & 0.495 & 0.703 \\
Self-Control & $0.44-0.79$ & 0.744 & 0.430 & 0.656 \\
Creativity & $0.52-0.62$ & 0.643 & 0.312 & 0.558 \\
Relational Support & $0.48-0.79$ & 0.714 & 0.464 & 0.681 \\
Need for Ach & $0.60-0.72$ & 0.606 & 0.436 & 0.661 \\
Entrepreneurial Behavior & $0.52-0.74$ & 0.839 & 0.468 & 0.684 \\
\hline
\end{tabular}


Table 6: Factor Loading

\begin{tabular}{lcc}
\hline Variables & $\begin{array}{c}\text { Composite Reliability } \\
\text { (AMOS) }\end{array}$ & $\begin{array}{c}\text { Construct reliability } \\
\text { (SPSS - Cronbach's Alpha ( } \boldsymbol{\alpha}) \text { ) }\end{array}$ \\
\hline Entrepreneurial Self Efficacy & 0.838 & 0.833 \\
Entrepreneurial Intention & 0.923 & 0.921 \\
Personal Attitudes & 0.827 & 0.820 \\
Educational Support & 0.743 & 0.822 \\
Self-Control & 0.744 & 0.735 \\
Creativity & 0.643 & 0.666 \\
Relational Support & 0.714 & 0.696 \\
Need for Achievement & 0.606 & 0.600 \\
Entrepreneurial Behavior & 0.839 & 0.837 \\
\hline
\end{tabular}

Table 7 Test of Reliability (A)

\begin{tabular}{|c|c|c|}
\hline Questionnaire ITEMS & $\begin{array}{l}\text { Factor Loading } \\
\text { (This Research) }\end{array}$ & $\begin{array}{c}\text { Factor Loading } \\
\text { (In Literature) }\end{array}$ \\
\hline I am determined to create a firm in the future. & 0.92 & $\begin{array}{l}0.94 \text { (Yurtkoru et } \\
\text { al. 2014) }\end{array}$ \\
\hline I have very seriously thought of starting a firm. & 0.87 & $\begin{array}{l}0.92 \text { (Yurtkoru et } \\
\text { al. 2014) }\end{array}$ \\
\hline I am determined to create a firm in the future. & 0.91 & $\begin{array}{l}0.92 \text { (Yurtkoru et } \\
\text { al. 2014) }\end{array}$ \\
\hline $\begin{array}{l}\text { I will make every effort to start and run my own } \\
\text { firm. }\end{array}$ & 0.75 & $\begin{array}{l}0.88 \text { (Yurtkoru et } \\
\text { al. 2014) }\end{array}$ \\
\hline $\begin{array}{l}\text { If I decided to be an entrepreneur, my close } \\
\text { network (from work, school, and neighborhood) } \\
\text { supports me. }\end{array}$ & 0.48 & $\begin{array}{c}0.88 \text { (Yurtkoru et } \\
\text { al. 2014) }\end{array}$ \\
\hline $\begin{array}{l}\text { If I decided to be an entrepreneur, my friends } \\
\text { support me. }\end{array}$ & 0.71 & $\begin{array}{l}0.82 \text { (Yurtkoru et } \\
\text { al. 2014) }\end{array}$ \\
\hline $\begin{array}{l}\text { If I decided to be an entrepreneur, my family } \\
\text { members support me. }\end{array}$ & 0.79 & $\begin{array}{l}0.87 \text { (Yurtkoru et } \\
\text { al. 2014) }\end{array}$ \\
\hline $\begin{array}{l}\text { Being an entrepreneur would entail great } \\
\text { satisfactions for me. }\end{array}$ & 0.71 & $\begin{array}{l}0.88 \text { (Yurtkoru et } \\
\text { al. 2014) }\end{array}$ \\
\hline $\begin{array}{l}\text { Among various options, I would rather be an } \\
\text { entrepreneur. }\end{array}$ & 0.85 & $\begin{array}{l}0.85 \text { (Yurtkoru et } \\
\text { al. 2014) }\end{array}$ \\
\hline $\begin{array}{l}\text { Being an entrepreneur implies more advantages } \\
\text { than disadvantages to me. }\end{array}$ & 0.76 & $\begin{array}{l}0.81 \text { (Yurtkoru et } \\
\text { al. 2014) }\end{array}$ \\
\hline $\begin{array}{l}\text { If I had the opportunity and resources, I'd like to } \\
\text { start a firm. }\end{array}$ & 0.62 & $\begin{array}{l}0.78 \text { (Yurtkoru et } \\
\text { al. 2014) }\end{array}$ \\
\hline $\begin{array}{l}\text { The education in university encourages me to } \\
\text { develop creative ideas for being an entrepreneur. }\end{array}$ & 0.83 & $\begin{array}{l}0.90 \text { (Yurtkoru et } \\
\text { al. 2014) }\end{array}$ \\
\hline $\begin{array}{l}\text { My university develops my entrepreneurial skills } \\
\text { and abilities. }\end{array}$ & 0.62 & $\begin{array}{l}0.89 \text { (Yurtkoru et } \\
\text { al. 2014) }\end{array}$ \\
\hline $\begin{array}{l}\text { My university provides the necessary knowledge } \\
\text { about entrepreneurship. }\end{array}$ & 0.64 & $\begin{array}{l}0.87 \text { (Yurtkoru et } \\
\text { al. 2014) }\end{array}$ \\
\hline
\end{tabular}


Table 8: Test of Reliability (B)

\begin{tabular}{lc}
\hline \multicolumn{1}{c}{ Variables } & $\begin{array}{c}\text { Reliability in Literature } \\
\text { (as per anchor articles) }\end{array}$ \\
\hline Entrepreneurial Self Efficacy & 0.960 \\
Entrepreneurial Intention & 0.940 \\
Personal Attitudes & 0.900 \\
Educational Support & 0.910 \\
Self-Control & 0.820 \\
Creativity & 0.700 \\
Relational Support & 0.780 \\
Need for Achievement & 0.650 \\
Entrepreneurial Behavior & 0.920 \\
\hline
\end{tabular}

